\title{
KVALITET I STABILNOST BRAČNOG ODNOSA U RAZLIČITIM FAZAMA BRAKA*
}

Brojna istraživanja, iz drugih zemalja, ukazuju da prelaz iz bračnog razdoblja bez dece u bračno razdoblje kada supružnici dobijaju decu, nužno menja i otežava bračne odnose. Takođe je utvrđeno da majčinstvo znatno više deluje na život žene, nego što očinstvo deluje na život muškarca. Istraživanja pokazuju da dolazi do promena i u narednim fazama braka, ali su nalazi za celokupni bračni tok nekonzistentni - od ustanovljenih promena u kvalitetu bračnog odnosa u obliku slova U, do nalaza da kvalitet bračnog odnosa ima stalnu tendenciju pada. Imajući u vidu kulturno-istorijske specifičnosti našeg podneblja, cilj istraživanja prikazanog ovim radom je bio da utvrdi postoje li značajne razlike u kvalitetu i stabilnosti bračnog odnosa između grupa žena koje se nalaze u različitim fazama braka, i, ukoliko postoje, kakve su strukture tih razlika u odnosu na bračna razdoblja. Utvrđeno je da se grupe žena koje pripadaju različitim bračnim razdobljima međusobno značajno razlikuju, i to tako da žene u svakoj narednoj bračnoj fazi percipiraju svoj bračni odnos manje kvalitetnim, a istovremeno stabilnijim. Rezultati ovog transferzalnog istraživanja govore u prilog pretpostavkama da prelazak na roditeljstvo značajno povećava stabilnost braka, a da kvalitet, i posebno zadovoljstvo brakom, konstantno opada kako se prelazi iz jednog bračnog razdoblja u drugo, od početka do kraja bračnog kontinuuma. Ove pretpostavke svakako treba proveriti longitudinalnim istraživanjem u našoj sredini. Međutim, ne sme se gubiti iz vida da, bez obzira što postoje statistički značajne međugrupne razlike, između žena koje se nalaze u istom bračnom razdoblju postoje i velika individualna odstupanja, te samo na osnovu bračnih razdoblja nije moguće vršiti pouzdane individualne predikcije.

Ključne reči: brak, faze braka, bračni odnosi, kvalitet braka,bračna nestabilnost.

\section{UVOD}

Teorija socijalne razmene je najviše citiran teorijski okvir u istraživanjima bračnih i bliskih odnosa, a njene osnovne postavke su dali Thibaut i Kelley (1959) u Teoriji međuzavisnosti. Prema ovoj teoriji, bliske veze se razvijaju, rastu, propadaju i raspadaju se kao posledica razvijanja procesa socijalne razmene, odnosno razmene dobitaka i gubitaka među samim partnerima i između partnera $\mathrm{i}$ ostalih ljudi.

\footnotetext{
jelenas@neobee.net

Istraživanje prikazano ovim radom predstavlja deo projekta "Efekti egzistencijalne nesigurnosti na pojedinca i porodicu u Srbiji”, koji finansira Ministarstvo prosvete i nauke Republike Srbije (DN 179022).
} 
Levinger (1976) je bio prvi autor koji je Teoriju međuzavisnosti primenio na bračne odnose. Prema njegovom Modelu kohezivnosti partnerskog odnosa, (ne) uspeh braka zavisi od tri varijable, i njihovog individualnog vrednovanja, to su:

1. privlačnosti unutar veze,

2. prisustva poželjnije alternative van veze, $i$

3. barijera vezanih za raskid veze.

Pretpostavlja se da su ove tri varijable u stalnom procesu dinamičke povezanosti, i da je bračna stabilnost u potpunosti determinisana njihovim međuodnosom. Pri tom, privlačnost unutar veze (među bračnim partnerima) može biti: psihološka, telesna, materijalna i/ili statusna.

Poželjnija alternativa van veze može biti emocionalna i/ili seksualna veza sa drugim partnerom, koji se iz nekog razloga doživljava privlačnijim od bračnog partnera, ali isto tako, alternativa aktuelnoj vezi/braku može biti i samački život ili profesionalna karijera za koju su postojeći brak i bračne obaveze doživljeni kao otežavajući faktor.

Barijere vezane za raskid veze, odnosno prepreke za razvod, su najčešće zajednička deca i/ili različita uverenja o braku kao instituciji, i uverenja o psihološkim posledicama razvoda (npr. razvode se samo gubitnici, razvod bi značio da sam ja neuspešna osoba, deca iz razvedenih brakova su po pravilu problematična i sl.).

Bračna stabilnost je veća što je veća privlačnost unutar bračne veze (psihološka, telesna, materijalna i statusna), što je manje poželjnijih opcija van veze i što su jače barijere vezane za razvod braka.

U skladu s postavkama Levinger-ovog Modela kohezivnosti partnerskog odnosa (1976), brakovi se završavaju kada su ispunjena sledeća tri uslova:

1. privlačnost same veze je niska,

2. postoji poželjnija alternativa u odnosu na postojeću vezu i

3. barijere za napuštanje veze su slabe.

Karakteristike bračnog odnosa se menjaju tokom zajedničkog života supružnika. Pri tom bračni partneri, generalno, imaju dva tipa zadataka; to su: zadaci unutar granica bračnog odnosa, i zadaci van granica bračnog odnosa. Prvi podrazumevaju održavanje različitih vidova privrženosti među partnerima, uspostavljanje određenih obrazaca komunikacije i načina za prevazilaženje bračnih konflikata; a drugi se tiču odnosa sa porodicama porekla, prijateljima, institucijama, i decom, ukoliko ih imaju. U zadatke van granica bračnog odnosa spadaju i formiranje različitih uloga i njihovo balansiranje (Mihić, 2007).

Bračna razdoblja se najčešće dele (prema Čudina-Obradović i Obradović, 2006) na:

1. početak braka i razdoblje bez dece,

2. rođenje deteta i rano detinjstvo dece,

3. razdoblje školske dece, $\mathrm{i}$

4. razdoblje odrasle dece. 
Navedena klasifikacija bračnih razdoblja (koja ujedno predstavlja i faze životnog ciklusa porodice) se zasniva na reproduktivnoj funkciji braka, koja nije jedina funkcija braka, ali je različiti autori često navode kao osnovnu (npr. Sternberg \& Hojjat, 1997). Ovakva klasifikacija upućuje na visoku međusobnu povezanost bračnih i roditeljskih uloga.

Prelazi iz jednog bračnog razdoblja u drugo podrazumevaju bračne krize, odnosno, periode tokom kojih partneri i njihov odnos postaju vulnerabilni, jer njihov dotadašnji način funkcionisanja mora da se reorganizuje u susretu sa novim izazovima (Cox, Paley, Burchinal \& Payne, 1999).

Podaci o razvodima, međunarodnih statističkih zavoda (prema Čudina-Obradović i Obradović, 2006), i nalazi istraživanja (Karney \& Bradbury, 1995; Rao \& Sekhar, 2002), ukazuju da se najčešće razvode mlađi bračni partneri.

Preduzeta su brojna istraživanja kako bi se proverilo postoje li značajne razlike u kvalitetu braka u odnosu na različita bračna razdoblja; i kako bi se utvrdilo koji činioci kako utiču na kvalitet bračnog odnosa, tokom pojedinih bračnih razdoblja. Najveći broj tih istraživanja je bio usmeren na pitanje efekata rođenja prvog deteta na bračni odnos. Rezultati ovih istraživanja pokazuju da se percepcija kvaliteta bračnog odnosa i bračno zadovoljstvo kod oba partnera smanjuju nakon dobijanja deteta (Ade-Ridder \& Brubacker, 1983; Belsky, Spanier \& Rovine, 1983; Belsky, Huston \& Lang,1986; Belsky \& Rovine, 1990; Glenn, 1990; Cowan \& Cowan, 1992; Crawford \& Huston, 1993; Shapiro, Gottman \& Carrere, 2000; Obradović i Čudina-Obradović, 2001). Takođe, pokazuju da se zadovoljstvo brakom, dolaskom deteta u porodicu, posebno smanjuje kod žena (Ade-Rider \& Braubacker, 1983; Chester, 1982; Belsky et al., 1983; Belsky, Lang \& Rovine, 1985; Belsky \& Pensky, 1988), odnosno, da majčinstvo znatno više deluje na život žene, nego što očinstvo deluje na život muškarca (Nomaguchi \& Milkie, 2003). Na značajnu povezanost roditeljske i bračne uloge upućuju i nalazi istraživanja koji govore da deca u braku predstavljaju značajnu „,barijeru za razvod” (npr. Knoester \& Booth 2000), kao i nalaz da su negativne emocionalne posledice razvoda braka znatno izraženije kod žena koje su majke nego kod žena koje nemaju decu (Williams \& Dunne-Bryant, 2006).

Pad u percepciji kvaliteta bračnog odnosa, i posebno pad bračnog zadovoljstva, se objašnjava povećanjem broja životnih uloga - rođenje deteta i formiranje roditeljskih uloga partnerima nužno donosi dužnosti koje ometaju njihovo do tada uobičajeno funkcionisanje, što menja i otežava bračne odnose (Belsky et al., 1986; Belsky \& Rovine, 1990; Cowan \& Cowan, 1992; Crawford \& Huston, 1993).

Razloge za to što je percepcija opadanja kvaliteta bračnog odnosa znatno veća kod žena, nego kod muškaraca, autori ovih istraživanja pronalaze u činjenici da je u većini društava (kako tradicionalnih, tako i modernih) žena znatno opterećenija roditeljskom ulogom od muškarca (Weiss, 1998).

Rezultati istraživanja ukazuju da se žene, u poređenju sa muškarcima, češće žale na probleme u braku i da uočavaju više bračnih problema (Amato \& Rodgers, 1997). Muškarci mnoge bračne probleme ne uočavaju ili ih smatraju nevažnim 
(Thompson \& Walker, 1989). Pored bračne i profesionalne uloge, žene po pravilu nose i najveći deo odgovornosti obavljanja kućnih poslova i staranja o deci (Taylor, Bennett \& Sung, 2010), te se zaključuje da zbog toga ispoljavaju viši nivo psihološkog stresa, depresije i anksioznosti nego njihovi supružnici (Barnett, 2004).

Rezultati različitih istraživanja, sprovedenih u našoj sredini, takođe, dosledno ukazuju da su žene-majke značajno više od muškaraca uključene u svakodnevne poslove u domaćinstvu i u brigu o deci (Mihić, Zotović i Petrović, 2006; Petrović, 2007; Petrović, Mihić, Zotović i Kapor- Stanulović, 2009; Mihić i Zotović, 2011).

U nekim istraživanjima je zaključeno da upravo pad bračnog zadovoljstva kod žena utiče na percepciju smanjenja kvaliteta bračnog odnosa kod muškaraca (Waldorn \& Routh, 1981; Shapiro et al., 2000).

Utvrđeno je, međutim, i da se u nekim brakovima s rođenjem deteta ne smanjuje percepcija kvaliteta bračnog odnosa, te je zaključeno da postoje određeni faktori otpornosti prema smanjenju kvaliteta bračnog odnosa (Wright, Henggler \& Craig, 1986). Značajnim prediktorima uspešne postporođajne bračne adaptacije žena su se pokazali: visok stepen suprugovog bračnog zadovoljstva tokom njene trudnoće, željenost/planiranje te trudnoće od strane žene, i „neproblematičan” temperament novorođenčeta (Wright et al., 1986).

Rezultati jednog longitudinalnog istraživanja (MacDermid, Huston \& McHale, 1990), sugerišu da rođenje deteta nije uzrok smanjenja kvaliteta bračnog odnosa, jer do pada kvaliteta bračnog odnosa isto tako dolazi i u brakovima bez dece.

Rezultati istraživanja su dosledno potvrđivali i pretpostavke da postoje značajne razlike u kvalitetu bračnog odnosa između različitih bračnih razdoblja, a ne samo u periodu prelaska na roditeljstvo (Anderson, Russell \& Schumm, 1983; Glenn, 1989; Ross, Mirowsky \& Goldsteen, 1990). Nalazi pojedinih istraživanja (Ross et al., 1990; Shek, 1995) ukazuju da između kvaliteta bračnog odnosa i bračnih razdoblja postoji zakrivljen odnos, u obliku slova „U“. Pod ovim se podrazumeva da je u percepciji oba bračna partnera najveći stepen kvaliteta bračnog odnosa u bračnom razdoblju bez dece, zatim se percipirani kvalitet bračnog odnosa, u drugom i trećem razdoblju (nakon dobijanja deteta, tokom ranog detinjstva dece i njihovog školovanja) smanjuje, a kada deca odrastu, u četvrtom bračnom razdoblju, opet dolazi do porasta u percepciji kvaliteta bračnog odnosa.

Pojedini autori su ustanovili da dolazi do naglog pada u bračnom zadovoljstvu tokom prvih 10 godina braka, i do laganog povećanja bračnog zadovoljstva nakon 25 godina braka. Pri tom je zaključeno da dobijanje dece negativno utiče na bračno zadovoljstvo, jer smanjuje interakciju među bračnim partnerima i dovodi do značajnih promena u bračnim ulogama, dok odlazak „dece” od kuće ima pozitivne efekte na bračno zadovoljstvo (Glenn, 1990).

Navedeni rezultati su izazvali dosta polemike i prigovora, pre svega zato što većina tih istraživanja nisu bila longitudinalna, već transferzalna (Valliant \& Valliant, 1993). Imajući to u vidu, Valliant i Valliant (1993) su punih 40 godina pratili ispitanike - od studentskih dana do njihove 65 . godine života i zaključili su da je opi- 
sana U-kriva metodološki artefakt. Oni su utvrdili da do pada u bračnom zadovoljstvu ipak dolazi, ali u periodu kada su potomci adolescentnog uzrasta. Takođe su ustanovili da su žene generalno manje zadovoljne brakom.

Na osnovu jednog kasnijeg longitudinalnog istraživanja (Shapiro et al., 2000) na 130 bračnih parova, koji su praćeni šest godina nakon stupanja u brak, zaključeno je da nakon rođenja deteta značajno opada kvalitet bračnog odnosa, i to prvo u percepciji žena, a potom i kod muškaraca. Utvrđeno je da nakon rođenja deteta žene ispoljavaju manje nežnosti prema partneru i generalno mu poklanjaju manje pažnje, a to onda utiče na smanjenje kvaliteta bračnog odnosa u percepciji muškaraca i na smanjenje njihovog bračnog zadovoljstva (Shapiro et al., 2000).

Bračni staž se, uz držanje pod kontrolom prisustva dece u porodici i bračnih razdoblja, takođe, pokazao kao značajan prediktor kvaliteta bračnog odnosa (White \& Booth, 1985; Glenn, 1989; McLanahan \& Adams, 1989; Glenn, 1995; Orbuch, Hause, Mero \& Webster, 1996). Utvrđeno je da se kvalitet bračnog odnosa menja u funkciji vremena, odnosno da se menja nezavisno od toga da li bračni par ima decu ili ne: u početku partneri percepiraju visok kvalitet bračnog odnosa, a zatim, u nekoj najnižoj tački, doživljaj kvaliteta bračnog odnosa izvesno vreme stagnira, a onda polako počinje da raste - promene su u obliku velikog slova „U“.

U nekim drugim istraživanjima iz tog vremena, i posebno u kasnijim longitudinalnim istraživanjima, takođe sprovedenim u SAD-u, nisu potvrđeni nalazi o postojanju odnosa u obliku slova „U“ između dužine braka i kvaliteta bračnog odnosa (Glenn, 1998; Kurdek, 1999). Rezultati tih istraživanja su pokazivali da nema poboljšanja u doživljaju kvaliteta bračnog odnosa, već da postoji samo doživljaj pada kvaliteta - on počinje već nakon nekoliko godina braka, posebno je značajan nakon 10 godina, zatim se pad u doživljaju kvaliteta bračnog odnosa usporava, ali se nikada više ne povećava.

Twenge, Campbell i Foster (2003) su meta-analizom ustanovili: da partneri koji imaju decu izveštavaju o nižem zadovoljstvu bračnim odnosom u poređenju sa partnerima bez dece; da je ovaj efekat znatno veći kod žena; da postoji negativna korelacija između zadovoljstva vezom i broja dece (zadovoljstvo bračnom vezom se smanjuje sa povećanjem broja dece); kao i da je kod žena-majki zadovoljstvo najmanje dok su deca mala, dok je kod očeva efekat podjednak za sve uzraste dece.

Imajući u vidu kulturno-istorijske specifičnosti našeg podneblja i aktuelnu društveno-ekonomsku krizu, značajno je proveriti koliko se navedni istraživački nalazi o promenama u bračnom funkcionisanju kroz različita bračna razdoblja mogu primeniti u našoj sredini.

Uzimajući u obzir nalaze istraživanja koji govore da je bračno zadovoljstvo žena značajniji prediktor bračne stabilnosti, od bračnog zadovoljstva muškaraca (Heaton, 2002; Heaton \& Blake, 1999); te nalaze da je ženina percepcija kvaliteta bračnog odnosa prvi i najvažniji faktor koji vodi ka razvodu ili pomaže u njegovoj prevenciji (Karney \& Bradbury, 1995; Cross \& Madson, 1997); istraživanje, čiji prikaz sledi, sprovedeno je samo na populaciji žena. 
U cilju utvrđivanja karakteristika kvaliteta i stabilnosti bračnog odnosa u različitim fazama braka, analizirane su strukture razlika u percepciji kvaliteta i stabilnosti bračnog odnosa između žena koje su u različitim bračnim razdobljima, i posebno između žena koje su u prvoj i drugoj bračnoj fazi - onih koje su na početku braka, u razdoblju bez dece, i žena koje su u drugoj bračnoj fazi koja podrazumeva rođenje deteta i njegovo rano detinjstvo.

\section{METOD}

Uzorak. Ispitano je 1614 žena, starosti od 19 do 69 godina ( $\mathrm{AS}=36,97 ; \mathrm{SD}=7,25)$, koje žive u formalnom $(89,4 \%)$ ili neformalnom $(10,6 \%)$ braku između godinu dana i 45 godina $(A S=12,54 ; S D=7,65)$. Njihovi partneri su stari od 22 do 71 godine $(\mathrm{AS}=40,09 ; \mathrm{SD}=7,73)$. Najveći broj ovih parova ima stan u vlasništvu $(67,8 \%)$; $16,5 \%$ stanuje kod roditelja jednog od supružnika, dok ostali žive kao podstanari. Ukupne mesečne prihode u domaćinstvu skoro polovina ispitanica procenjuje prosečnim (48,7\%); 20,2\% ispitanica ocenjuje da su im prihodi nešto iznad prosečnih; $3,8 \%$ da su im prihodi znatno iznad prosečnih, dok $15,8 \%$ ispitanica procenjuje da su im prihodi nešto ispod prosečnih, a 11,5\% ocenjuje da su prihodi njihovog domaćinstva znatno ispod prosečnih.

Nešto više od polovine ispitanica ima završenu srednju školu (54\%), a zatim sledi broj ispitanica koje su završile fakultet $(29,9 \%)$ i višu školu (8,7\%). Uzorkom je obuhvaćen i znatan broj žena sa poslediplomskim obrazovanjem (3,7\%), ali i onih koje imaju završenu samo osnovnu školu $(3,4 \%)$ i onih žena koje nisu završile ni osnovnu školu (4\%). Slično je distribuirano i obrazovanje njihovih partnera (4\% partnera nije završilo ni osnovnu školu, 5,2\% ima završenu osnovnu školu, 59,5\% srednju školu, $10 \%$ višu školu, $21,5 \%$ ih ima fakultetsko, a 3,5\% i poslediplomsko obrazovanje).

Većina ispitanica je u radnom odnosu (od toga: 12,1\% na određeno vreme, 53\% na neodređeno, a 6,2\% su (su)vlasnice preduzeća); $0,9 \%$ ispitanica je u penziji, njih $13,7 \%$ se izjašnjavaju kao domaćice, dok ih $14,1 \%$ traži posao i izjašnjavaju se kao „trenutno nezaposlene”. Među njihovim partnerima ima $15,1 \%$ nezaposlenih; $14,9 \%$ je zaposlenih na određeno, a 52,3\% na neodređeno vreme; njih $15,3 \%$ su (su)vlasnici nekog preduzeća, a 2,4\% su penzioneri.

Iz statističkih analiza u ovom radu su isključene ispitanice koje nemaju decu, a nisu u početnoj fazi braka, jer ih je bilo malo, i ispitanice koje imaju decu, ali nisu dale podatke o njihovoj starosti. Ukupni uzorak ispitanica na kom su vršene diskriminativne analize tako broji 1580 žena. Među njima, 50,3\% žena ima dvoje dece, $23,9 \%$ ima jedno dete, njih $12,3 \%$ nemaju decu, $9,2 \%$ ima troje dece, dok preostalih 4,3\% ispitanica ima četvoro ili više dece.

Distribucija ispitanica po poduzorcima, u odnosu na bračna razdoblja, prikazana je u tabeli 1. Pripadnost različitim bračnim fazama u ovom radu je određena starošću ispitanicinog prvog deteta. Ovo je uobičajeni kriterijum za određenje bračnih razdoblja, jer se rođenjem prvog deteta uspostavlja raspodela poslova i 
odgovornosti u novom načinu porodičnog funkcionisanja, gde pored bračnih, partneri razvijaju i roditeljske uloge. Međutim, imajući u vidu mogućnost da žena ima više dece u različitim razvojnim fazama, u narednim radovima treba ispitati razlike u kvalitetu i stabilnosti bračnog odnosa, uzimajući u obzir i drugačije kriterijume za određenje bračnih faza (npr. uzimajući u obzir starost najmlađeg deteta).

Tabela 1. Raspodela ispitanica po poduzorcima u odnosu na pripadnost različitim bračnim razdobljima

\begin{tabular}{llll}
\hline Bračno razdoblje & Frekvencije & Procenat & Kumulativni procenti \\
\hline 1. Bez dece & 194 & 12.3 & 12.3 \\
2. Mala deca & 312 & 19.7 & 32.0 \\
3. Osnovna škola & 653 & 41.3 & 73.4 \\
4. Srednja škola & 239 & 15.1 & 88.5 \\
5. Odrasla deca & 182 & 11.5 & 100.0 \\
Ukupno & 1580 & 100.0 & \\
\hline
\end{tabular}

Postupak. Ispitivanje je, u saradnji sa stručnim saradnicima - psiholozima, sprovedeno na teritoriji Republike Srbije, pri čemu 42\% ispitanih žena živi u Novom Sadu i Beogradu, a 58\% u manjim mestima i selima (Sremskoj Mitrovici i okolnim selima, Somboru i okolnim selima (Staparu, Bezdanu, Bačkom Monoštoru, Bačkom Bregu, Aleksi Šantiću), Bačkoj Palanci, Rumi, Inđiji, Novim Banovcima, Staroj Pazovi, Šapcu, Loznici, Bačkom Brestovcu, Kucuri). Najveći broj ispitanica je kontaktiran na roditeljskim sastancima u školama (osnovnim i srednjim) i vrtićima, gde im je ukratko objašnjen cilj istraživanja i predloženo anonimno učešće u istraživanju, na dobrovoljnoj osnovi. Žene koje su prihvatile učešće u istraživanju su dobile upitnike i koverte. Odgovarale su kod kuće i popunjene upitnike vraćale vaspitačicama i razrednim starešinama u zatvorenim kovertama. Ispitivanje žena iz brakova bez dece je prvenstveno vršeno preko ginekoloških ordinacija, a u manjoj meri i putem interneta (preko različitih mailing lista i internet grupa).

Instrumenti. Kvalitet bračnog odnosa je meren Skalom prilagođenosti u bračnom odnosu (Dyadic Adjustment Scale - DAS: Spanier, 1976; 1989), koja je u izvornim istraživanjima pokazala zadovoljavajuće psihometrijske karakteristike (Spanier, 1976) i predstavlja jedan od najčešće primenjivanih instrumenata u istraživanjima bračnog kvaliteta, a po nekim studijama je i najčešće korišćen instrument za merenje bračnog kvaliteta (Glenn, 1990). DAS se sastoji od 32 ajtema na koje ispitanici odgovaraju tako što procenjuju stepen učestalost određenih ponašanja, ili procenjuju da li su neka ponašanja prisutna u njihovoj vezi. Skala, pored izračunavanja ukupnog skora, nudi mogućnost izračunavanja skorova i na sledećim subskalama:

1. „Konsenzus” (sastoji se od 13 stavki kojima se procenjuje slaganje bračnih partnera po pitanjima koja su od značaja za svakodnevno funkcionisanje: vođenje finansija, odnos prema kućnim obavezama, religiji, rekreaciji, odnos prema prijateljima, roditeljima i rođacima, životnoj filozofiji, donošenju odluka i sl.); 
2. „Zadovoljstvo brakom” (sadrži 10 stavki koje se odnose na opšte zadovoljstvo brakom, poverenje u partnera, učestalost bračnih konflikta, stepen bračne tenzije, doživljaj međusobne netrpeljivosti i lični odnos prema budućnosti braka);

3. „Afektivno-seksualna usaglašenost” (obuhvata 4 ajtema kojima se procenjuje stepen usaglašenosti bračnih partnera u ispoljavanju emocija i seksualnim odnosima); i

4. „Kohezivnost” (obuhvata 5 stavki koje se odnose na stepen bliskosti i kvaliteta komunikacije među partnerima: zajednički rad na nekom ostvarenju, smireni razgovori, podsticanje razmene ideja, zajednička interesovanja van kuće, zajednički smeh).

5. Na podacima prikupljenim ovim istraživanjem, ustanovljena je zadovoljavajuća pouzdanost instrumenta merena Kronbahovim Alfa koeficijentom i za skalu u celini $(0,94)$ i za pojedinačne subskale (za Konsenzus iznosi 0,89; Zadovoljstvo 0,88; Kohezivnost 0,81; a za Afektivno-seksualnu usaglašenost 0,62). Bračna stabilnost je merena Indeksom bračne nestabilnosti (Martial Instability Index: Booth, Johnson \& Edwards, 1983). Instrument uključuje sledeće tri stavke: prisustvo razmišljanja o razvodu braka, postojanje razgovora sa prijateljima o razvodu, i postojanje razgovora o razvodu braka sa bračnim partnerom. Odgovara se potvrdno ili odrično, a skorovi se kreću u rasponu od 3 do 9, pri čemu niži rezultati ukazuju na bračnu stabilnost, a viši na bračnu nestabilnost. Na podacima prikupljenim ovim istraživanjem, ustanovljena je dobra pouzdanost instrumenta (Kronbahov Alfa koeficijent iznosi 0,96).

U cilju utvrđivanja strukture razlika u kvalitetu bračnog odnosa i stabilnosti braka između žena koje se nalaze u različitim fazama braka, i u cilju utvrđivanja strukture razlika u kvalitetu bračnog odnosa i stabilnosti braka između žena u prvoj i drugoj bračnoj fazi, primenjene su diskriminativne analize.

\section{REZULTATI}

$\mathrm{U}$ tabeli 2 su dati osnovni rezultati sprovedene diskriminativne analize $\mathrm{u}$ odnosu na različite faze braka.

Tabela 2. Rezultati diskriminativne analize u odnosu na različita bračna razdoblja

\begin{tabular}{ccccccccc}
\hline $\mathrm{F}$ & $\lambda$ & $\begin{array}{c}\% \\
\text { varijanse }\end{array}$ & $\begin{array}{c}\text { Kumulativni } \\
\% \text { varijanse }\end{array}$ & $\mathrm{rc}$ & $\begin{array}{c}\text { Wilksova } \\
\lambda\end{array}$ & $\chi 2$ & $\mathrm{df}$ & $\mathrm{p}$ \\
\hline 1 & 0,073 & 85,8 & 85,8 & 0,260 & 0,921 & 116,679 & 20 & 0,000 \\
2 & 0,008 & 9,0 & 94,8 & 0,087 & 0,988 & 16,982 & 12 & 0,150 \\
3 & 0,004 & 4,5 & 99,3 & 0,061 & 0,996 & 6,203 & 6 & 0,401 \\
4 & 0,001 & 0,7 & 100,0 & 0,025 & 0,999 & 0,856 & 2 & 0,652 \\
\hline
\end{tabular}

$\mathbf{F}$ - izolovana diskriminativna funkcija; $\boldsymbol{\lambda}$ - karakterističan koren diskriminativnog faktora; \% varijanse - procenat varijanse objašnjene diskriminativnim faktorom; rc - koeficijent kanoničke korelacije; Wilksova $\lambda$ - mera razlika centroida grupa; $\chi 2$ - test značajnosti Wilksove $\lambda$; $\mathbf{d f}$ - broj stepeni slobode; $\mathbf{p}$ - nivo značajnosti diskrim. funkcije. 
Kao što se može videti iz tabele 1 , utvrđena je samo jedna statistički značajna diskriminativna dimenzija, na nivou $p=0,00$; a ona objašnjava $85,8 \%$ međugrupne varijanse. Koeficijent kanoničke korelacije iznosi $r=0,26$ i govori o postojanju, iako statistički značajne, relativno niske izraženosti razlika među grupama, na ovoj diskriminativnoj dimenziji. Struktura diskriminativnog faktora je prikazana u tabeli 3 .

Tabela 3. Matrica strukture diskriminativnog faktora

\begin{tabular}{lc}
\hline Varijabla & Korelacija \\
\hline Zadovoljstvo & 0,556 \\
Kohezivnost & 0,454 \\
Afektivno-seksualna usaglašenost & 0,399 \\
Bračna nestabilnost & 0,306 \\
Konsenzus & 0,268 \\
\hline
\end{tabular}

Kao što se može videti iz matrice strukture, izolovani diskriminativni faktor je u najvećoj meri određen bračnim zadovoljstvom, zatim percepcijom kohezivnosti, a onda percepcijom afektivno-seksualne usaglašenosi partnera. Izolovana diskriminativna dimenzija je u manjoj meri određena i bračnom nestabilnošću, odnosno potencijalom za razvod.

Dakle, visoki skorovi na diskriminativnom faktoru upućuju na visok stepen zadovoljstva sopstvenim brakom (visoko opšte zadovoljstvo brakom, izraženo poverenje u partnera, skladan odnos bez većih konfilkata, odsustvo međusobne netrpeljivosti...), visok stepen bliskosti i kvaliteta komunikacije među partnerima (česti su: zajednički rad na nekom ostvarenju, smireni razgovori, podsticanje razmene ideja, zajednička interesovanja van kuće, zajednički smeh), visok je stepen usaglašenosti bračnih partnera u ispoljavanju emocija i seksualnim odnosima, ali istovremeno i izraženija bračna nestabilnost.

Dobijeni diskriminativni faktor je, u skladu sa Levinger-ovim (1976) Modelom kohezivnosti partnerskog odnosa, interpretiran kao „visoka privlačnost unutar veze praćena sniženim barijerama vezanim za raskid veze".

Tabela 4. Centroidi grupa na diskriminativnom faktoru

\begin{tabular}{lc}
\hline Grupa & Centroidi \\
\hline Bez dece & 0,590 \\
Mala deca & 0,098 \\
Osnovna škola & $-0,035$ \\
Srednja škola & $-0,238$ \\
Odrasla deca & $-0,391$ \\
\hline
\end{tabular}


Kao što se može videti na osnovu veličine i predznaka centroida grupa (tabela 4), prosečna vrednost na diskriminativnoj dimenziji grupe žena koje još uvek nemaju decu je najbliža polu sa visokim skorovima, dok su prosečne vrednosti odgovora za žene koje imaju decu u svakoj narednoj fazi sve pomerenije ka nižim skorovima diskriminativnog faktora. Dakle, ovom diskriminativnom funkcijom su najbolje razdvojene žene iz prve i poslednje bračne faze, iz bračnog odnosa gde još uvek nisu rođena deca i bračnog odnosa koji potomci napuštaju. Raspršenje odgovora na diskriminativnoj dimenziji, za poduzorke žena iz različitih bračnih faza, prikazano je na grafikonu 1.

Grafikon 1. Raspršenje odgovora na diskriminativnom faktoru

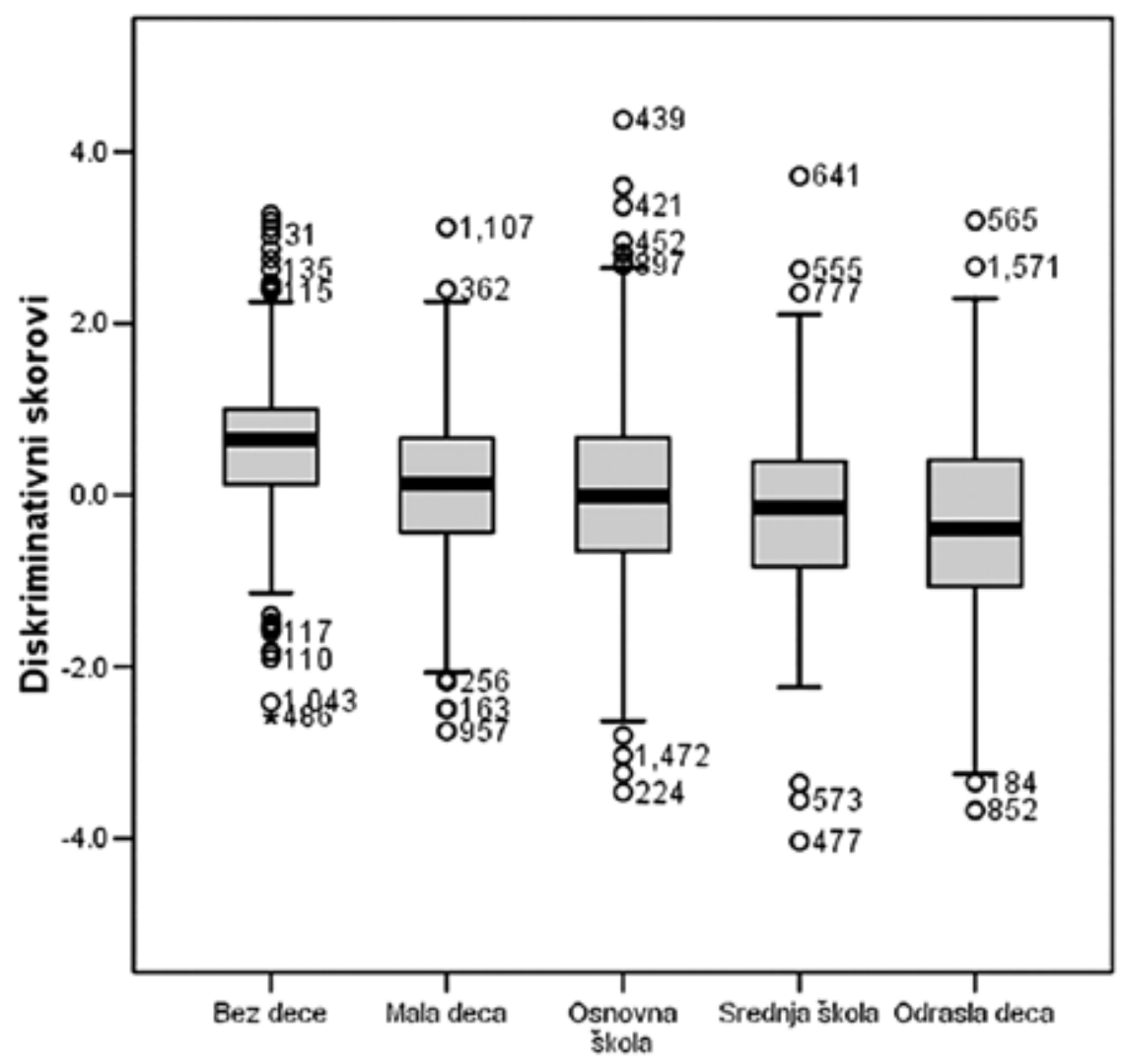

Faza braka

Kao što se može videti na grafikonu 1, iako postoji veliki raspon diskriminativnih skorova za sve grupe ispitanica, može se reći da je u proseku za žene koje žive u braku bez dece najkarakterističnija visoka privlačnost unutar veze, ali i najniže barijere vezane za raskid veze; u svakoj narednoj bračnoj fazi je nešto niža pri- 
vlačnost unutar same veze, a ujedno su sve izraženije barijere vezane za raskid veze/razvod braka; tako da je za žene koje žive u braku sa odraslom „decom”, u razdoblju odvajanja potomaka, u proseku najkarakterističniji bračni odnos sa niskom privlačnošću unutar veze, ali i sa najizraženijim barijerama vezanim za raskid veze, odnosno, iako su najmanje zadovoljne kvalitetom svog bračnog odnosa, istovremeno su najmanje spremne da se razvedu.

Tabela 5 Rezultati klasifikacije odgovora na diskriminativnom faktoru

\begin{tabular}{lccccccc}
\hline & & \multicolumn{3}{c}{ Predviđeno članstvo u grupi } & Suma \\
\hline & Faza braka & $\begin{array}{c}\text { Bez } \\
\text { dece }\end{array}$ & $\begin{array}{c}\text { Mala } \\
\text { deca }\end{array}$ & $\begin{array}{c}\text { Osnovna } \\
\text { škola }\end{array}$ & $\begin{array}{c}\text { Srednja } \\
\text { škola }\end{array}$ & $\begin{array}{c}\text { Odrasla } \\
\text { deca }\end{array}$ \\
& Bez dece & 106 & 27 & 15 & 11 & 22 & 181 \\
\multirow{5}{*}{ Stvarne } & Mala deca & 82 & 66 & 36 & 38 & 66 & 288 \\
grupe & Osnovna škola & 168 & 93 & 92 & 80 & 146 & 579 \\
& Srednja škola & 38 & 52 & 24 & 47 & 56 & 217 \\
& Odrasla deca & 32 & 19 & 15 & 31 & 64 & 161 \\
\hline
\end{tabular}

Ispravno je klasifikovano $26.3 \%$ ispitanika.

Ipak, treba biti oprezan pri uopštavanju ovih rezultata, pošto je samo $26,3 \%$ ispitanica ispravno klasifikovano na osnovu ove diskriminativne dimenzije (što se može videti u tabeli 5), a u svim grupama postoje žene i sa izrazito niskim i sa izrazito visokim diskriminativnim skorovima (što se može videti na grafikonu 1).

U tabeli 6 su prikazani osnovni rezultati diskriminativne analize u odnosu na pripadnost prvom ili drugom bračnom razdoblju.

Tabela 6. Rezultati diskriminativne analize u odnosu na pripadnost jednom od prva dva bračna razdoblja

\begin{tabular}{ccccccccc}
\hline $\mathrm{F}$ & $\lambda$ & $\begin{array}{c}\% \\
\text { varijanse }\end{array}$ & $\begin{array}{c}\text { Kumulativni } \\
\% \text { varijanse }\end{array}$ & $\mathrm{rc}$ & $\begin{array}{c}\text { Wilksova } \\
\lambda\end{array}$ & $\chi 2$ & $\mathrm{df}$ & $\mathrm{p}$ \\
\hline 1 & 0.07 & 100 & 100 & 0.25 & 0.94 & 31.17 & 5.00 & 0.00 \\
\hline
\end{tabular}

$\mathbf{F}$ - izolovana diskriminativna funkcija; $\boldsymbol{\lambda}$ - karakterističan koren diskriminativnog faktora; \% varijanse - procenat varijanse objašnjene diskriminativnim faktorom; rc - koeficijent kanoničke korelacije; Wilksova $\boldsymbol{\lambda}$ - mera razlika centroida grupa; $\boldsymbol{\chi 2}$ - test značajnosti Wilksove $\lambda$; $\mathbf{d f}$ - broj stepeni slobode; $\mathbf{p}$ - nivo značajnosti diskrim. funkcije.

Kao što se može videti iz tabele 6, dobijena je značajna diskriminativna dimenzija. Koeficijent kanoničke korelacije iznosi $r=0,25(\mathrm{p}=0,00)$ i govori o postojanju, iako statistički značajne, relativno niske izraženosti razlika među grupama, na ovoj diskriminativnoj dimenziji. Struktura diskriminativnog faktora je prikazana u tabeli 7 . 
Tabela 7. Matrica strukture diskriminativnog faktora

\begin{tabular}{lc}
\hline Varijabla & Korelacija \\
\hline Bračna nestabilnost & 0.48 \\
Zadovoljstvo & 0.37 \\
Kohezivnost & 0.18 \\
Ekspesivnost & 0.13 \\
Konsenzus & 0.03 \\
\hline
\end{tabular}

Kao što se može videti u matrici strukture, izolovani diskriminativni faktor je u najvećoj meri određen bračnom nestabilnošću, odnosno visokim potencijalom za razvod braka, a zatim bračnim zadovoljstvom.

Dakle, visoki skorovi na ovom diskriminativnom faktoru predstavljaju izraženu nestabilnost braka, a ujedno i visok stepen zadovoljstva sopstvenim brakom (visoko poverenje u supruga, skladan odnos bez većih konfilkata...).

Dobijeni diskriminativni faktor je, poput prethodnog, u skladu sa Levingerovim (1976) Modelom kohezivnosti partnerskog odnosa, interpretiran kao „niske barijere za razvod praćene visokom privlačnošću unutar veze".

Tabela 8 Centroidi na diskriminativnom faktoru

\begin{tabular}{lc}
\hline Grupa & Centroidi \\
\hline Bez dece & 0.33 \\
Mala deca & -0.21 \\
\hline
\end{tabular}

Kao što se može videti na osnovu veličine i predznaka centroida grupa (tabela 8), prosečna vrednost na diskriminativnoj dimenziji grupe žena koje nemaju decu je bliža visokim diskriminativnim skorovima, dok je za prosečna vrednost odgovora na ovom disakriminativnom faktoru za žene koje imaju decu pomerena ka nižim diskriminativnim skorovima. Drugim rečima, za žene koje nemaju decu su, u proseku, karakterističnije „niske barijere za razvod praćene visokom privlačnošću unutar veze", dok su za žene koje imaju malu decu, u proseku, veće barijere za razvod, a niža privlačnost unutar veze. Raspršenje odgovora grupa žena sa i bez dece na diskriminativnoj dimenziji prikazano je na grafikonu 2.

Iako postoji veliki raspon diskriminativnih skorova za obe grupe ispitanica, može se reći da je u proseku za žene koje žive u braku bez dece karakterističnije veće zadovoljstvo brakom, ali i veća otvorenost za prekid veze/braka, dok je, s druge strane, za žene koje žive u braku sa malom decom, u proseku, nešto karakterističniji bračni odnos kojim su manje zadovoljne, ali su isto tako i manje spremne da se razvedu. Ipak, treba biti oprezan pri uopštavanju ovih rezultata, pošto je samo $64 \%$ ispitanica ispravno klasifikovano na osnovu utvrđene diskriminativne dimenzije (što se može videti u tabeli 9), a u obe grupe postoje žene i sa izrazito niskim i sa izrazito visokim diskriminativnim skorovima (što se može videti na grafikonu 2). 
Grafikon 2. Raspršenje odgovora na diskriminativnom faktoru

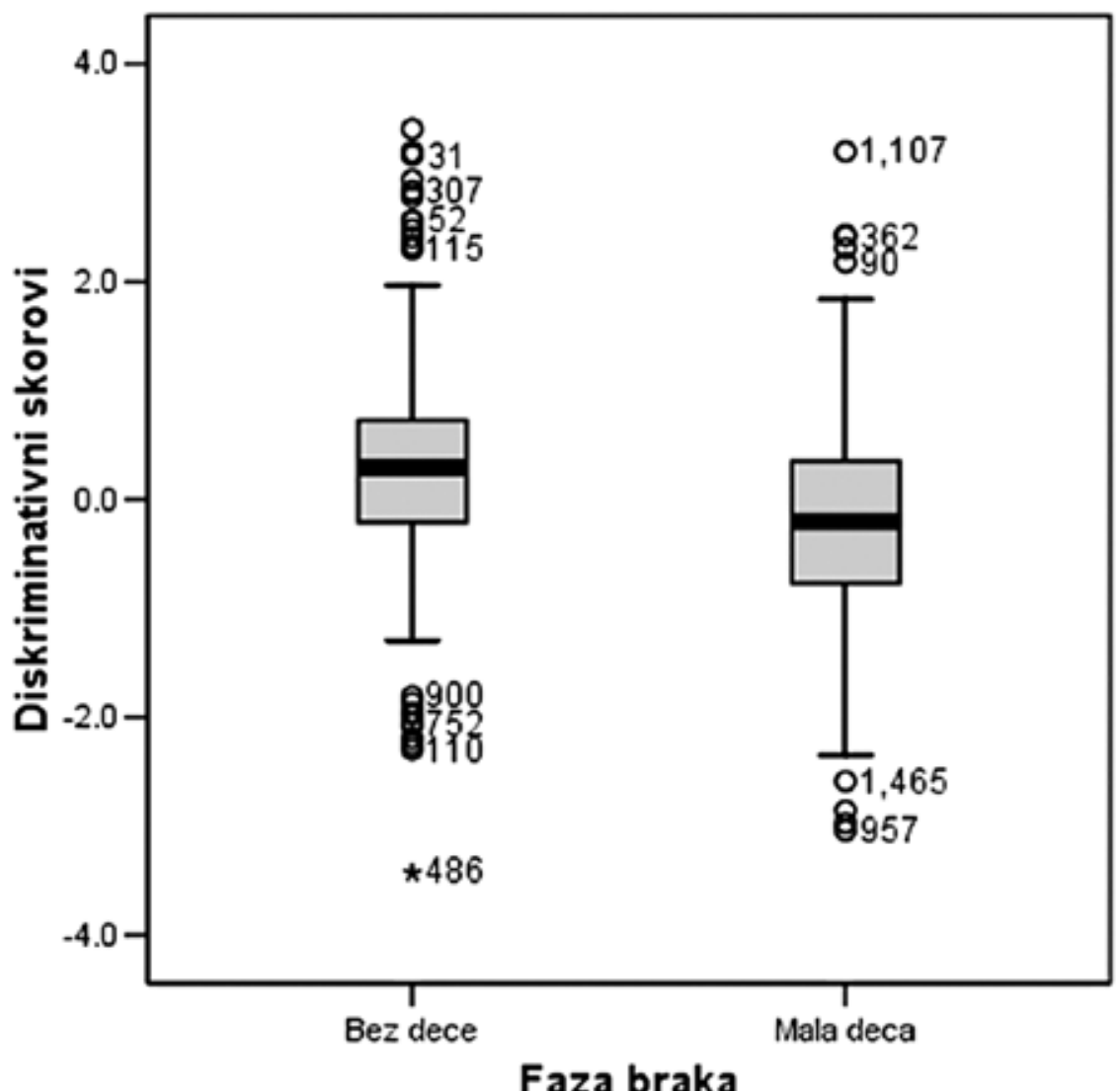

Tabela 9 Rezultati klasifikacije odgovora na diskriminativnom faktoru

\begin{tabular}{ccccc}
\hline & & \multicolumn{2}{c}{ Predviđeno članstvo u grupi } & Suma \\
\hline \multirow{3}{*}{ Stvarne grupe } & Faza braka & Bez dece & Mala deca & \\
& Bez dece & 113 & 68 & 181 \\
& Mala deca & 101 & 187 & 288 \\
\hline
\end{tabular}

Ispravno je klasifikovano $64.0 \%$ ispitanika.

\section{DISKUSIJA}

Iako su rezultati pojedinih istraživanja (Ross et al., 1990; Shek, 1995) sugerisali da između kvaliteta bračnog odnosa i bračnih razdoblja postoji zakrivljen odnos, u obliku slova „U“; a rezultati drugih istraživanja (White \& Booth, 1985; Glenn, 1989; McLanahan \& Adams, 1989; Glenn, 1995; Orbuch, Hause, Mero \& Webster, 
1996) su sugerisali da se kvalitet bračnog odnosa menja u funkciji vremena, nezavisno od toga da li bračni par ima decu ili ne, te da u početku partneri percepiraju visok kvalitet bračnog odnosa, a zatim, u nekoj najnižoj tački, doživljaj kvaliteta bračnog odnosa izvesno vreme stagnira, a onda polako počinje da raste - takođe $u$ obliku velikog slova „U“; rezultati istraživanja prikazanog ovim radom ne podržavaju ni jednu od ovih pretpostavki. Nalazi ovog istraživanja su bliži rezultatima istraživanja koja su ukazivala da nema poboljšanja u doživljaju kvaliteta bračnog odnosa, već da vremenom dolazi samo do doživljaja pada kvaliteta bračnog odnosa (Glenn, 1998; Kurdek, 1999), ili makar do smanivanja bračnog zadovoljstva.

Ustanovljeno je da je, u proseku, za žene iz prvog bračnog razdoblja (koje još uvek žive u u braku bez dece) najkarakterističnija visoka privlačnost unutar veze, ali i niske barijere vezane za raskid veze; dok je u svakoj narednoj bračnoj fazi nešto niža privlačnost unutar same veze, a ujedno su sve izraženije barijere vezane za raskid veze/razvod braka; tako da je za žene koje žive u braku sa odraslom ,decom”, u razdoblju odvajanja potomaka, u proseku najkarakterističniji bračni odnos sa niskom privlačnošću unutar veze, ali i sa najizraženijim barijerama vezanim za raskid veze. U razdoblju kada „deca” odlaze, i ne predstavljaju više „opravdan” razlog da se „sačuva” nezadovoljavajući brak, moguće je da barijere za razvod predstavljaju negativni stavovi o razvodu (npr. da je sramota razvesti se, posebno „pod stare dane" i sl.). Ovu pretpostavku, međutim, treba proveriti u narednim istraživanjima u našoj sredini.

Rezultati ovog istraživanja govore u prilog ranijim nalazima (Anderson et al., 1983; Glenn, 1989; Ross et al., 1990) da postoje statistički značajne razlike u percepciji kvaliteta bračnog odnosa između žena koje se nalaze u bračnom razdoblju bez dece i žena koje imaju dete/decu u fazi ranog detinjstva. Može se zaključiti da je u proseku za žene koje još uvek žive u braku bez dece karakterističnije veće zadovoljstvo brakom, ali i veća otvorenost za prekid veze/braka, dok je, s druge strane, za žene koje žive u braku s decom, u proseku, nešto karakterističniji bračni odnos kojim su manje zadovoljne, ali su isto tako i manje spremne da se razvedu. Utvrđeni rezultati, poput nalaza istraživanja do koga su došli Knoester i Booth (2000), ukazuju da deca u braku jesu barijera za razvod (u skladu sa Levinger-ovim (1976) Modelom kohezivnosti partnerskog odnosa). Međutim, ne sme se gubiti iz vida da se samo oko dve trećine (64\%) od ukupnog broja ispitanih žena zaista „uklapa” u ovaj opis, dok je čak za nešto više od trećine ispitanih žena (36\%) navedeni opis neadekvatan. Postoje velike razlike i među ženama koje se nalaze u bračnom razdoblju bez dece i među ženama koje imaju dete/decu u fazi ranog detinjstva, tako da treba biti vrlo oprezan pri zaključivanju i/ili predviđanju vezanom za neki individualni slučaj.

Kako razumeti dobijene rezultate?!

Sprovedenim istraživanjem je utvrđeno da su za žene u početnoj fazi braka, u proseku, karakterističniji zadovoljavajući-nestabilni, a za žene u braku sa decom, 
nezadovoljavajući-stabilni bračni odnosi. Na osnovu ovog nalaza je opravdano zaključiti da deca u braku predstavljaju jedan od značajnih stabilizatora braka, a ujedno su i prepreka za razvod, kako to predviđa Teorija socijalne razmene.

$\mathrm{Na}$ osnovu ovog nalaza se, takođe, može pretpostaviti da kod žena postoji veliki nesklad između očekivanja od braka i onog što su dobile brakom. Jedno od mogućih objašnjenja jeste da su žene koje još nemaju dete, mada zadovoljne onim što realno imaju, ipak očekivale i još uvek se nadaju da (možda s nekim drugim partnerom) mogu dobiti znatno više - više sreće i blagostanja ili znatno manje neugodnih emocija. Odnosno, stiče se utisak da veruju da su mogle „i bolje proći” iako je kvalitet veze zadovoljavajući. Na ovu pretpostavku ukazuju njihova razmatranja razvoda braka, i pored procene zadovoljavajućeg kvaliteta bračnog odnosa. U terminima Levinger-ovog Modela kohezivnosti, može se reći da ovi bračni odnosi imaju slabije barijere za napuštanje veze i/ili neku poželjniju alternativu (što ne mora nužno biti drugi partner, već može npr. biti i profesionalna karijera za koju su bračne obaveze doživljene kao ograničavajući faktor).

Prema dobijenim rezultatima, možemo pretpostaviti i da će kod najvećeg broja ovih žena, nakon dobijanja deteta, rasti nezadovoljstvo bračnim odnosom, ali da će istovremeno sve manje razmatrati razvod, jer će s jedne strane pažnju s bračnog preusmeriti na roditeljski odnos, a, s druge strane alternativa jednoroditeljskog porodičnog funkcionisanja se ne čini privlačnijom od nezadovoljavajućeg braka; i verovatno će o razvodu nastaviti da razmišljaju (i eventualno da ga realizuju) samo one žene koje bračni kvalitet procenjuju izuzetno lošim (za njih „,nepodnošljivim").

Sa stanovišta utilitarnog morala, koji je svojstven sve prisutnijem, i kod nas, „modernom” individualističkom sistemu vrednosti, bračna zajednica bi morala supružnicima i njihovim potomcima da obezbedi osećanje sreće i blagostanja, ukoliko je funkcionalna/ispravna; dok se hronično nezadovoljstvo i frustriranost smatraju jasnim pokazateljima neispravnog, disfunkcionalnog bračnog odnosa. U tom smislu zadovoljavajući-stabilan bračni odnos je jedina poželjna i zdrava opcija (bračni odnos niskog potencijala za razvod koji prati percepcija visokog bračnog kvaliteta, po svim parametrima).

Međutim, problem je u tome što mnogi ljudi prirodno želeći zadovoljavajući-stabilan bračni odnos, i težeći mu, gube iz vida da ni jedan bračni odnos ne može biti bez bračnih konflikata, različitih problema u porodici i van nje, (nekada manjih, a nekada i velikih) neizvesnosti, ličnih frustracija i svih drugih neugodnih osećanja. Takođe, mnogi nastoje da „sebe realizuju” i „ostvare u potpunosti”, „kroz” kvalitetan bračni odnos, a pri tom previđaju da je formiranje ličnog identiteta i samoprihvatanje nužan preduslov za razvoj kvalitetnog partnerskog odnosa (Šakotić-Kurbalija, 2011).

U nastavku istraživanja bi bilo značajno utvrditi razlike između žena koje svoje brakove procenjuju nestabilnim, ali još uvek nisu donele odluku o pokretanju procesa razvoda, grupe žena koje su pokrenule proces razvoda braka i grupe već razvedenih žena, jer bračni odnosi mogu biti konstantno nestabilni (,stabilno 
nestabilni”, „stalno na ivici razvoda”), što je veliki izvor stresa za sve članove te porodice, pa je nekada najzdraviji ishod - razvod braka.

Na kraju, važno je podsetiti da, bez obzira na postojanje statistički značajnih međugrupnih razlika, među ženama koje se nalaze u istoj bračnoj fazi postoje velika individualna odstupanja, te samo na osnovu bračnih razdoblja nije moguće vršiti pouzdanu predikciju percepcije kvaliteta i stabilnosti bračnog odnosa.

\section{LITERATURA}

Ade-Ridder, L. \& Brubacker, T.H. (1983). The quality of long-term marriages. In: Brubacker T.H. (Ed.). (1983). Family Relationships in Later Life. Beverly Hills: Sage Publications.

Amato, P. R. \& Rogers, S. J. (1997). A longitudinal study of marital problems and subsequent divorce. Journal of Marriage and Family, 59 (3), 612-624.

Anderson, S. A., Russell, C. S. \& Schumm, W. R. (1983). Percived marital quality and family life - cycle categories: A further analysis. Journal of Marriage and the Family, 45, 127-139.

Barnett, R. C. (2004). Women and Multiple Roles: Myths and reality. Harvard Review of Psychiatry, 12 (3), 158-164.

Belsky, J. \& Kelly, J. (1994). The transition to parenthood: How a First Child Changes a Marriage: which Couples Grow Closer Or Apart. New York: Delacorte Press.

Belsky, J. \& Pensky, E. (1988). Marital change across the transition to parenthood. Marriage \& Family Review, 12, 133-156.

Belsky, J. \& Rovine, M. (1990). Patterns of Marital Change across the Transition to Parenthood: Pregnancy to Three Years Postpartum. Journal of Marriage and Family. Vol. 52(1), pp. 5-19.

Belsky, J., Spanier, G. B. \& Rovine, M. (1983). Stability and Change in Marriage Across the Transition to Parenthood. Journal of Marriage and Family, 45, 567-578.

Belsky, J., Huston, T. L. \& Lang, M. (1986). Sex typing and division of labor as determinants of marital change across the transition to parenthood. Journal of Personality and Social Psychology, vol. 50, 517-522.

Booth, A., Johnson, D. \& Edwards, J. N. (1983). Measuring Martial Instability. Journal of Marriage and the Family, 45, 387-393.

Cowan, C. P. \& Cowan, P. A. (1992). When partners become parents: The big life change for couples. New York, NY, US: Basic Books.

Cox, M. J., Paley, B., Burchinal, M. \& Payne, C. C. (1999). Marital Perceptions and Interactions Across the Transition to Parenthood. Journal of Marriage and Family, 61, 611-625.

Crawford, D. W. \& Huston, T. L. (1993). The impact of the transition to parenthood on marital leisure. Personality and Social Psychology Bulletin, Vol 19(1), 39-46.

Cross, S.E. \& Madson, L. (1997). Models of the self: Self-Construals and gender. Psychological Bulletin, 122, 5-37.

Čudina-Obradović, M. \& Obradović, J. (2006). Psihologija braka i obitelji. Zagreb: Golden marketing- Tehnička knjiga.

Glenn, N.D. (1989). Duration of marriage, family composition and marital happiness. Natl. J. Soc. 3, 3-24.

Glenn, N. D. (1995). Marital quality. In D. Levinson (Ed.) (1995). Encyclopedia of marriage and the family (pp. 448-455). New York: Simon \& Schuster Macmillan. 
Glenn, N. D. (1998). The course of marital success and failure in five American 10-year marriage cohorts. Journal of Marriage and the Family, 60, 569-576.

Glenn, N.D. (1990). Quantitative research on marital quality in the 1980s: A critical review. Journal of Marriage and the Family, vol.52, 818-831.

Heaton, T. B., \& Blake, A. M. (1999). Gender differences in determinants of marital disruption. Journal of Family Issues, 20, 25-45.

Heaton, T.B. (2002). Factors contributing to increasing marital stability in the United States. Journal of Family Issues, 23, 392-409.

Karney, B. R. \& Bradbury, T. N. (1995). Assessing longitudinal change in marriage: An introduction to the analysis of growth curves. Journal of Marriage and the Family, 57, 1091-1108.

Knoester, C. \& Booth, A. (2000). Barriers to divorce: When are they effective? When are they not? Journal of Family Issues, Vol 21(1), 78-99.

Kurdek, L.A. (1999). The nature and predictors of the trajectory of change in marital quality for husbands and wives over the first 10 years of marriage. Developmental Psychology, Vol 35(5), 1283-1296.

Levinger, G. (1976). A social psychological perspective on marital dissolution. Journal of Social Issues, Vol 32(1), 21-47.

MacDermid, S M., Huston, T. L. \& McHale, S. M. (1990). Changes in marriage associated with the transition to parenthood: Individual differences as a function of sex-role attitudes and changes in the division of household labor. Journal of Marriage and Family, 52, 475-486.

McLanahan, S. \& Adams, J. (1989). The effects of children on adults' psychological wellbeing: 1957-1976. Social Forces, Vol 68(1), 124-146.

Mihić, I. (2007). Roditeljstvo u porodicama sa adolescentom: faktori kvaliteta. Beograd: Zadužbina Andrejević.

Mihić, I. \& Zotović, M. (ured.) (2011). Porodične i profesionalne uloge: značaj zaposlenja za porodično funkcionisanje. Novi Sad: Filozofski fakultet, Odsek za psihologiju.

Mihić, I., Zotović, M. \& Petrović, J. (2006). Sociodemografske karakteristike porodice, podela posla u kući i vaspitni stilovi roditelja u porodicama na teritoriji Vojvodine. Pedagoška stvarnost, 1-2, 118-134.

Nomaguchi, K. M. \& Milkie, M. A. (2003). Costs and Rewards of Children: The Effects of Becoming a Parent on Adults. Journal of Marriage \& Family, 65, 356-374.

Obradović, J. \& Čudina-Obradović, M. (2001). Broj djece u obitelji i spol bračnog partnera kao prediktori bračne kvalitete. Društvena istraživanja, 10, 4-5, 709-730.

Orbuch, T.L.; House, J.S.; Mero, R.P. \& Webster, P.S. (1996). Marital quality over the life course. Social Psychology Quarterly, Vol 59(2), 162-171.

Petrović, J. (2007). Odnosi u porodicama u Vojvodini: podela uloga, vaspitno ponašanje roditelja i porodična klima. U: Zotović, M. (ured.) (2007). Porodice u Vojvodini: karakteristike i funkcionalnost. Novi Sad: Filozofski fakultet.

Petrović, J., Mihić, I., Zotović, M. \& Kapor-Stanulović, N. (2009). Porodične uloge oca i majke u porodicama u procesu tranzicije. Zbornik Matice srpske za društvene nauke, (128), 31-45.

Rao, A.B.S.V.R. \& Sekhar, K.(2002). Divorce: Process and Correlates A Cross-Cultural Study. Journal of Comparative Family Studies, Vol. 33 Issue 4, p541-564.

Ross, C. E., Mirowsky, J. \& Goldsteen, K. (1990). The Impact of the Family on Health: The Decade in Review. Journal of Marriage and Family, Vol. 52, No. 4, Family Research in the 1980s: The Decade in Review, 1059-1078. 
Šakotić-Kurbalija, J. (2011). Povezanost zavisnosti u partnerskim odnosima sa kompleksom inferiornosti. Godišnjak Filozofskog fakulteta, Novi Sad, 36(2), 207-218.

Shapiro, A. F., Gottman, J. M. \& Carrère, S. (2000). The Baby and the Marriage: Identifying Factors That Buffer Against Decline in Marital Satisfaction After the First Baby Arrives. Journal of Family Psychology, 14, 59-70.

Shek, D. T. (1995). Gender differences in marital quality and well-being in Chinese married adults. Sex Roles, 32, 669-715.

Spanier, G.B. (1989). Manual for the dyadic adjustment scale. North Tonowanda, New York: Multi-Health Systems.

Sternberg, R.J. \& Hojjat, M. (1997). Satisfaction in close relationships. New York: The Guilford Press.

Taylor, S., Bennett, F. \& Sung, S. (2010). Unequal but "fair"? Housework and child care in a sample of low to moderate income British couples. Barnett Papers in Social Research 2010-4, Department of Social Policy and Intervention, University of Oxford.

Thibaut, J.W. \& Kelley, H.H. (1959). The social psychology of groups. Oxford, England: John Wiley.

Thompson, L. \& Walker, A. J. (1989). Gender in families: Women and men in marriage, work, and parenthood. Journal of Marriage and Family, 51 (4), 845-871.

Twenge, J. M., Campbell W. K. \& Foster C. A. (2003). Parenthood and Marital Satisfaction: A Meta-Analytic Review. Journal of Marriage and Family, 65, 574-583.

Valliant, C. \& Valliant, G. (1993). Is the U-curve of marital satisfaction an illusion? A 40-year study of marital satisfaction. Journal of Marriage and the Family, vol. 55, 230-239.

Waldron, H. \& Routh, D.K. (1981). The effect of the first child on the marital relationship. Journal of Marriage \& the Family, Vol 43(4), 785-788.

Weiss, R.S. (1998). A taxonomy of relationships. Journal of Social and Personal Relationships, 15, 671-683.

White, L. K. \& Booth, A. (1985).The Transition to Parenthood and Marital Quality. Journal of Family Issues, 6, 435-449.

Williams, K., \& Dunne-Bryant, A. (2006). Divorce and adult psychological well-being: Clarifying the role of gender and child age. Journal of Marriage and Family, 68, 1178 - 1196.

Wright, J.P., Henggeler, S.W. \& Craig, L. (1986). Problems in paradise? A longitudinal examination of the transition to parenthood. Journal of Applied Developmental Psychology, 7, 277-291.

Jelena Šakotić-Kurbalija

\section{KVALITET I STABILNOST BRAČNOG ODNOSA U RAZLIČITIM FAZAMA BRAKA}

\section{REZIME}

Cilj istraživanja prikazanog ovim radom je bio da se utvrdi postoje li značajne razlike u odnosu na varijable kvaliteta i stabilnosti braka između žena koje se nalaze u različitim fazama braka; i da se utvrdi struktura tih razlika, ukoliko one postoje. Posebno je analizirana struktura razlika u karakteristikama bračnog odnosa između žena koje su u prvoj fazi braka, u bračnom razdoblju bez dece, i žena u narednoj bračnoj fazi, kada dolazi do rođenja dece, jer brojna istraživanja, iz 
drugih zemalja, ukazuju da prelaz na roditeljstvo nužno menja i otežava bračne odnose, kao i da majčinstvo znatno više deluje na život žene, nego što očinstvo deluje na život muškarca.

Uzorak ispitanica je obuhvatio 1580 žena, različitog socioekonomskog statusa, starosti od 19 do 64 god., koje žive u formalnom ili neformalnom braku. Kvalitet bračnog odnosa je meren Skalom prilagođenosti u bračnom odnosu (Dyadic Adjustment Scale - DAS: Spanier, 1989), a bračna stabilnost je merena Indeksom bračne nestabilnosti (Martial Instability Index: Booth, Johnson \& Edwards, 1983).

Diskriminativnom analizom, u odnosu na različita bračna razdoblja, utvrđena je samo jedna statistički značajna diskriminativna dimenzija $(\mathrm{Rc}=0,26, \mathrm{p}=0,00)$, koja je interpretirana kao „visoka privlačnost unutar veze praćena sniženim barijerama vezanim za raskid veze". Ova diskriminativna dimenzija najbolje razdvaja žene iz prve i poslednje bračne faze - žene iz bračnog odnosa gde još uvek nisu rođena deca i bračnog odnosa koji potomci napuštaju. Drugom diskriminativnom analizom, u odnosu na pripadnost prvoj ili drugoj bračnoj fazi, utvrđena je značajna diskriminativna dimenzija $(R c=0,25, p=0,00)$, određena prvenstveno bračnom nestabilnošću, a zatim bračnim zadovoljstvom. Rezultati ovog transferzalnog istraživanja govore u prilog pretpostavkama da prelazak na roditeljstvo značajno povećava stabilnost braka, a da kvalitet, i posebno zadovoljstvo brakom, konstantno opada kako se prelazi iz jednog bračnog razdoblja u drugo, od početka do kraja bračnog kontinuuma. Ove pretpostavke svakako treba proveriti longitudinalnim istraživanjem u našoj sredini. Međutim, ne sme se gubiti iz vida da, bez obzira što postoje statistički značajne međugrupne razlike, između žena koje se nalaze u istom bračnom razdoblju postoje i velika individualna odstupanja, te samo na osnovu bračnih razdoblja nije moguće vršiti pouzdane individualne predikcije.

Jelena Šakotić-Kurbalija

\section{CHARACTERISTICS OF MARITAL QUALITY AND STABILITY AMONG WIVES IN VARIOUS STAGES OF MARRIAGE}

\section{SUMMARY}

The main objective of the research presented in this paper was to determine whether or not there are significant differences in marital quality and stability among women in various stages of marriage, and to determine the structure of these differences, if they exist. We have also examined the differences in the characteristics of marriage between the wives in the first stage of marriage, i.e. the marriage period without children, and the wives in the next stage, after the childbirth. Those differences were analyzed separately because numerous studies from other countries suggest that the transition to parenthood changes marital relationships and makes them more difficult. The studies also suggest that the motherhood affects a wife's life much more to than fatherhood affects the life of the man. The sample included 1580 wives of different socioeconomic status, 19 to 64 years old, living in formal or informal marriage. The quality of the marital relationship was measured by a Dyadic Adjustment Scale - DAS (Spanier, 1989), and marital stability was assessed through the indicators of the potential for the divorce (Booth, Johnson, \& Edwards, 1983). Discriminant function analysis of the different periods of marriage, found only one statistically significant discriminant function $(\mathrm{Rc}=0.26, \mathrm{p}=0.00)$, which was interpreted as "High attractiveness of the marriage along with reduced barriers to leaving the relationship." The results are suggesting a downward tendency of the marital quality and marital satisfaction followed by the decrease in the divorce potential across the stages of marriage. In other words, there is a continual tendency of decreases in marital quality and satisfaction, and the increase of the marital stability over the different developmental stages of marriage. The greatest differences on isolated dicriminant function are between wives from the first and last of the examined stages of marriage, i.e. marriages in which the children are not yet born and marriages with late adolescent children that are ready to 
leave their parents. Second discriminant function analysis showed significant discriminative dimension $(\mathrm{Rc}=0.25, \mathrm{p}=0.00)$, primarily determined by the potential for divorce, and marital satisfaction. Based on the results of this study, we may conclude that the transition to parenthood significantly strengthens marriage, and that the perception of marital quality and satisfaction steadily declines from the beginning to the end of marriage continuum. It is important to emphasize that, despite the existence of statistically significant inter-group differences, there is a large individual variation among wives within the same marital stage, and therefore it is not possible to make a reliable prediction of perceptions of the quality and stability of marital relations based solely on the stage of the marriage.

Key words: marriage, stages of marriage, marital relations, marital quality, potential for divorce. 